\title{
Distribution and risk factors for spread of amphibian chytrid fungus Batrachochytrium dendrobatidis in the Tasmanian Wilderness World Heritage Area, Australia
}

\author{
Matthew D. Pauza ${ }^{1}$, Michael M. Driessen ${ }^{1, *}$, Lee F. Skerratt ${ }^{2}$ \\ ${ }^{1}$ Biodiversity Conservation Branch, Department of Primary Industries, Parks, Water and Environment, \\ PO Box 44, Hobart, Tasmania 7001, Australia \\ ${ }^{2}$ Amphibian Disease Ecology Group, School of Public Health, Tropical Medicine and Rehabilitation Sciences, \\ James Cook University, Townsville 4811, Australia
}

\begin{abstract}
Chytridiomycosis is an emerging infectious disease caused by the pathogen Batrachochytrium dendrobatidis $(B d)$ and is the cause of the decline and extinction of amphibian species throughout the world. We surveyed the distribution of $B d$ within and around the Tasmanian Wilderness World Heritage Area (TWWHA), a 1.38 million ha area of significant fauna conservation value, which provides the majority of habitat for Tasmania's 3 endemic frog species (Litoria burrowsae, Bryobatrachus nimbus and Crinia tasmaniensis). Bd was detected at only 1 (3\%) of the 33 sites surveyed within the TWWHA and at 15 (52\%) of the 29 sites surveyed surrounding the TWWHA. The relatively low incidence of the disease within the TWWHA suggests that the majority of the TWWHA is currently free of the pathogen despite the fact that the region provides what appears to be optimal conditions for the persistence of $B d$. For all survey sites within and around the TWWHA, the presence of $B d$ was strongly associated with the presence of gravel roads, forest and $<1000 \mathrm{~m}$ altitude-factors that in this study were associated with human-disturbed landscapes around the TWWHA. Conversely, the presence of walking tracks was strongly associated with the absence of $B d$, suggesting an association of absence with relatively remote locations. The wide distribution of $B d$ in areas of Tasmania with high levels of human disturbance and its very limited occurrence in remote wilderness areas suggests that anthropogenic activities may facilitate the dissemination of the pathogen on a landscape scale in Tasmania. Because the majority of the TWWHA is not readily accessible and appears to be largely free of $B d$, and because Tasmanian frogs reproduce in ponds rather than streams, it may be feasible to control the spread of the disease in the TWWHA.
\end{abstract}

KEY WORDS: Chytridiomycosis $\cdot$ Emerging disease $\cdot$ Frogs $\cdot$ Litoria $\cdot$ Crinia

\section{INTRODUCTION}

Chytridiomycosis is caused by the fungal pathogen Batrachochytrium dendrobatidis $(B d)$ and is recognised as an emerging infectious disease of amphibians (Williams et al. 2002, Daszak et al. 2003). It has been implicated as the causative agent responsible for numerous amphibian mortality events (Berger et al.
1998, Green \& Kagarise Sherman 2001, Lips et al. 2003a, Bell et al. 2004, La Marca et al. 2005, Diaz et al. 2007) and in the rapid decline and extinction of amphibian species throughout the tropical and temperate zones of Australasia (e.g. Berger et al. 1998, Bell et al. 2004, Skerratt et al. 2007), the Americas (e.g. Berger et al. 1998, Ron \& Merino 2000, Green et al. 2002, Muths et al. 2003, Lips et al. 2006), Africa (Wel- 
don 2002, Lane et al. 2003, Weldon et al. 2004) and Europe (e.g. Bosch et al. 2001, Garner et al. 2005).

Within Australia, $B d$ has a scattered distribution throughout most of the eastern seaboard from northern Queensland to Victoria, extending south to Tasmania, west to South Australia and the southwestern region of Western Australia (Berger et al. 2004, Speare et al. 2005). The threat posed by the pathogen has been recognised by the classification of chytridiomycosis as a 'key threatening process' pursuant to the Australian Government's Environmental Protection and Biodiversity Conservation Act 1999 and by the development of a Threat Abatement Plan (Australian Government Department of the Environment and Heritage 2006a).

The emergence of chytridiomycosis is thought to be due to its spread into naïve populations via initial anthropogenic introduction such as through the transportation of infected amphibians followed by natural spread (Skerratt et al. 2007, Lips et al. 2008). Importantly, no studies have investigated the anthropogenic risk factors associated with the distribution and spread of $B d$ on a small spatial scale, although these factors have been investigated with respect to frog disappearances (Witte et al. 2008). Most studies have focussed on the anthropogenic spread of $B d$ on a broad scale through the movement of infected amphibians (Parker et al. 2002, Mazzoni et al. 2003).

Environmental conditions across most of Tasmania are suitable for the establishment and persistence of $B d$, and the habitat and life history traits of the Tasmanian endemic anuran species are similar to those of anuran species occurring elsewhere whose decline has been linked to chytridiomycosis (Retallick 2003, Australian Government Department of the Environment and Heritage 2006b). Bd was first detected in Tasmania in 2004 and was subsequently found in 5 anuran species (Crinia signifera, C. tasmaniensis, Limnodynastes dumerili, L. tasmaniensis and Litoria ewingii) in urban and rural areas of the southeast and the central north (Obendorf 2005, Obendorf \& Dalton 2006). This wide distribution of the disease suggests that it was introduced to the state sometime before 2004, possibly by inadvertent translocation of infected frogs in imported fresh produce from mainland Australia or by the unauthorised importation of amphibians for pets. The majority of western Tasmania has not been surveyed for $B d$, particularly the Tasmanian Wilderness World Heritage Area (TWWHA), which plays a significant role in the conservation of Tasmania's vertebrate fauna including anurans (Driessen \& Mallick 2003). In particular, the distributions of Bryobatrachus nimbus and Litoria burrowsae are primarily restricted to the TWWHA. The other Tasmanian endemic anuran, $C$. tasmaniensis, is common and widely distributed in the TWWHA, but also occurs in other parts of Tasmania.
The aim of this study was to determine the presence and distribution of $B d$ within and immediately around the TWWHA, and to identify risk factors associated with the distribution of the disease in order to direct appropriate management actions.

\section{MATERIALS AND METHODS}

Study area. The study was focused on the TWWHA, one of the largest temperate wilderness areas in the southern hemisphere, encompassing over 1.38 million ha, or $20 \%$ of the Tasmanian land mass. The area is characterised by a mountainous landscape, low soil fertility and limited disturbance associated with European settlement (Driessen \& Mallick 2003). Based on 9 weather stations within or near the TWWHA, mean annual rainfall ranges from 1000 to $3000 \mathrm{~mm}$, mean annual minimum temperature ranges from 2 to $9^{\circ} \mathrm{C}$ and mean annual maximum temperature ranges from 12 to $16^{\circ} \mathrm{C}$ (Australian Government Bureau of Meteorology 2006). Dominant vegetation types are buttongrass moorland, rainforest, wet sclerophyll forest, wet scrub and alpine treeless communities. The remote location of, and limited vehicular access to, much of the TWWHA has resulted in minimal human impact in the region. Today, only a handful of commercial industries occur in the region, including beekeeping, ecotourism, hydro-electric power generation and commercial fishing (Driessen \& Mallick 2003).

Field sampling. Surveys for $B d$ were conducted between October 2005 and June 2007. We used historical location records of Litoria burrowsae (stored in the Tasmanian Natural Values Atlas, a computerised database maintained by the Department of Primary Industries and Water) to provide a base set of sampling sites because we were concurrently assessing the distribution of this endemic species (to be reported elsewhere). Additional sampling sites were added opportunistically to the base set to provide an overall spatial coverage of the TWWHA and the range of $L$. burrowsae. The remoteness of much of the TWWHA limited the number of sites that could be surveyed within the time available.

At each sampling site, the following environmental characteristics were recorded: altitude, aquatic $\mathrm{pH}$, vegetation type (forest or non-forest) and land tenure. Aquatic $\mathrm{pH}$ was determined using a $\operatorname{Hach}^{\mathrm{TM}} \mathrm{pH}$ test kit. The presence of anthropogenic disturbance factors within a $100 \mathrm{~m}$ radius of each sampling site was recorded using MapInfo Professional 8.0 GIS. The factors recorded were presence of gravel roads, bitumen roads, walking tracks (these indicated sites with the least human disturbance), fire trails and human infrastructure. 
Dectection of $\boldsymbol{B d}$. We broadly followed the protocol for mapping chytridiomycosis in amphibian populations in Australia (Speare et al. 2005, Skerratt et al. 2008). Tadpoles were used for chytridiomycosis assessment because sufficient numbers could be easily captured at each sampling site. Infection status at each sampling site was determined using a combination of visual assessment of mouth-part abnormalities consistent with chytridiomycosis infection (Obendorf \& Dalton 2006) and real-time Taqman polymerase chain reaction (PCR) assay (Boyle et al. 2004, Hyatt et al. 2007). By grading mouthpart abnormalities in the field, we were able to identify a subset of tadpoles that exhibited clinical signs of chytridiomycosis that could be used for follow-up Taqman PCR analysis. This greatly improved the cost-efficiency of our survey by reducing the number of tadpoles tested, but maintained our chances of detecting the disease by testing tadpoles most likely to be infected (Obendorf 2005, Obendorf \& Dalton 2006). Mouthpart abnormalities are a good indicator of chytridiomycosis in Litoria ewingii, Crinia tasmaniensis and C. signifera (Obendorf 2005, Obendorf \& Dalton 2006). Sixty tadpoles were collected from each site and visually assessed for mouthpart abnormalities and loss. A subset of 12 tadpoles, including any with mouthpart depigmentation and loss, or else a random sample, was swabbed individually by placing a fine-tip swab (MW100, Medical Wire and Equipment) on the mouthparts until the oral disc closed on the swab (Obendorf \& Dalton 2006). The 12 individuals sampled to confirm the absence of $B d$ was much less than the 60 individuals recommended by Speare et al. (2005) and Skerratt et al. (2008). However, minimum prevalences of $B d$ in Tasmanian tadpoles are higher than the $5 \%$ used by Speare et al. (2005) and Skerratt et al. (2008), and targeting tadpoles with mouthpart abnormalities improves the chances of detection. For example, a previous Tasmanian survey readily detected $B d$ in 33 of 56 sites by only testing up to 6 tadpoles at each site by PCR using similar methods of targeting tadpoles with abnormal mouthparts as above (Obendorf 2005, Obendorf \& Dalton 2006). All tadpoles were released unharmed at the point of capture. Adult anurans captured opportunistically at sampling sites were swabbed twice over their ventral, dorsal and lateral surfaces. Care was taken not to collect debris or dirt on the swab during the sampling of both tadpoles and frogs and to avoid cross contamination between swab samples. Swabs taken from tadpoles were pooled according to species then batched in 4 for testing so that each sampling site had a minimum of 3 batches comprising 4 swabs each (Hyatt et al. 2007). Batching of swabs provided a cost-effective method for PCR analyses that permitted additional sites to be assessed. Swabs taken from frogs were not pooled and were analysed individually. Pooled swabs were stored at $-10^{\circ} \mathrm{C}$ before transportation to James Cook University, where they were analysed in triplicate. A positive result for $B d$ presence was recorded if all 3 replicates of the PCR reacted.

All field operations were conducted in accordance with the hygiene protocols for disease control (Speare 2001). Equipment used in the field was washed down and disinfected with 95\% ethanol between successive sampling sites. An additional wash down and drying of equipment was undertaken between sampling periods.

Data analysis. Prevalence estimates were made using a pooled prevalence calculator (AusVet Animal Health Services, Australia, www.ausvet.com.au). We used logistic regression to determine the degree of association between site factors and the presence of $B d$. However, the unbalanced distribution and small number of sampling sites limited the power of the test and interpretation of results. Analysis was undertaken in SPSS version 15.0 with binary logistic models fitted to individual risk factors. Student's $t$-tests were used to assess differences in aquatic $\mathrm{pH}$ between infected and uninfected sites.

\section{RESULTS}

In total, 62 wetland sites were sampled for the presence of $B d$ within and around the TWWHA, with the pathogen detected at $26 \%(n=16)$ of sites with estimated prevalences for each species between 16 and $100 \%$ (Fig. 1, Table 1). Within the TWWHA, 33 sites were sampled, and only 1 (3\%) was infected. This site was adjacent to an access track to hydro-electric pylons and is within $1.5 \mathrm{~km}$ of the TWWHA boundary. The land tenures of sites surveyed within the TWWHA were national park and conservation area (Table 1). Outside the boundary of the TWWHA, 29 sites were sampled, and 15 (52\%) were infected. State Forest (11 sites) was the most common land tenure sampled outside the TWWHA, with the remaining sites occurring on various tenures (Table 1). Bd was detected at $69 \%$ of the State Forest sites and $39 \%$ of the pooled remaining sites (13) occurring outside the TWWHA.

The presence of $B d$ appeared to be strongly associated with sampling sites that had gravel roads (Table 2), but no significant association was found between the presence of $B d$ and roads sealed with bitumen, although the odds ratio was 0.24 (0.01-2.0).

The presence of $B d$ also appeared to be associated with sampling sites that had forest vegetation and were $<1000 \mathrm{~m}$ in elevation. This is unlikely to be a real effect of forest or elevation, instead reflecting a bias in the distribution of our sampling sites with these char- 


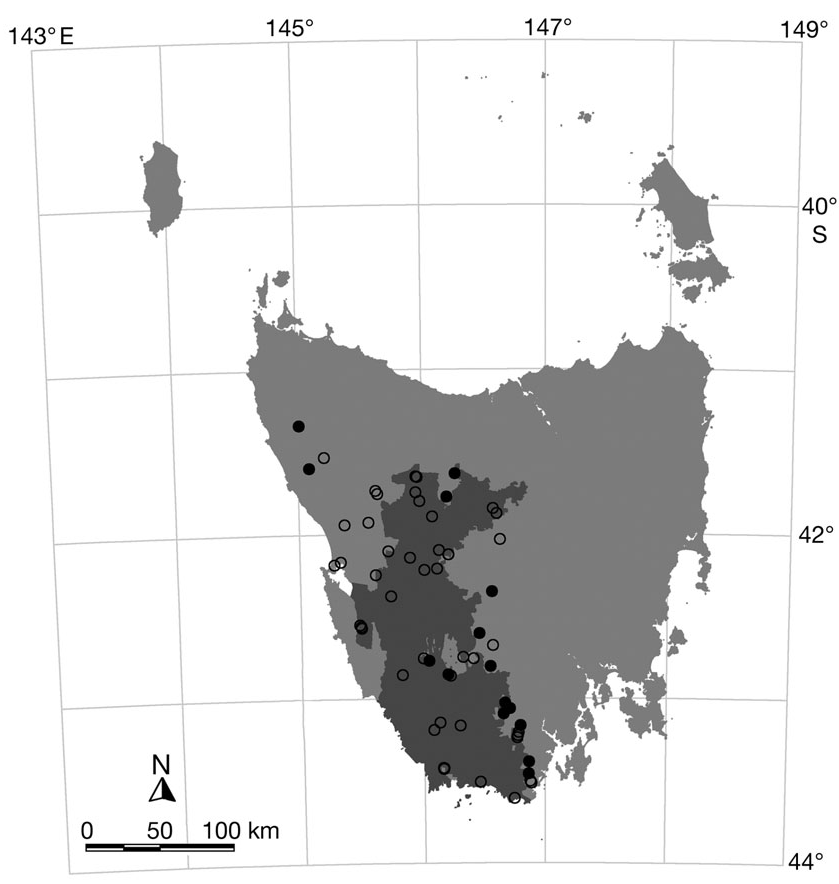

Fig. 1. Batrachochytrium dendrobatidis $(B d)$. Distribution of $B d$ within and around the Tasmanian Wilderness World Heritage Area (darker shading). $\bullet: B d$ positive, o: $B d$ negative

Table 1. Batrachochytrium dendrobatidis $(B d)$. Sites where $B d$ was detected and status of land tenure. TWWHA: Tasmanian Wilderness World Heritage Area

\begin{tabular}{|c|c|c|c|c|}
\hline \multirow[t]{2}{*}{ Land tenure } & \multicolumn{2}{|c|}{$B d$ present } & \multicolumn{2}{|c|}{$B d$ absent } \\
\hline & $\begin{array}{l}\text { Within } \\
\text { TWWHA }\end{array}$ & $\begin{array}{l}\text { Outside } \\
\text { TWWHA }\end{array}$ & $\begin{array}{l}\text { Within } \\
\text { TWWHA }\end{array}$ & $\begin{array}{c}\text { Outside } \\
\text { TWWHA }\end{array}$ \\
\hline National parks ${ }^{\mathrm{a}}$ & 1 & 0 & 27 & 1 \\
\hline 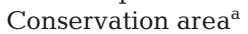 & 0 & 1 & 5 & 1 \\
\hline Nature reserve $^{\mathrm{a}}$ & 0 & 1 & 0 & 0 \\
\hline Regional reserve $^{\mathrm{a}}$ & 0 & 0 & 0 & 4 \\
\hline Private reserve $^{b}$ & 0 & 1 & 0 & 0 \\
\hline State forest & 0 & 11 & 0 & 5 \\
\hline Hydro Tasmania & 0 & 1 & 0 & 0 \\
\hline $\begin{array}{l}\text { Unallocated Crown } \\
\text { land }\end{array}$ & 0 & 0 & 0 & 3 \\
\hline Total & 1 & 15 & 32 & 14 \\
\hline
\end{tabular}

acteristics towards areas of human disturbance in State Forest outside the TWWHA (e.g. no sites $>1000$ m elevation were surveyed in disturbed locations). Conversely, walking tracks (i.e. areas that were not readily accessible) were strongly associated with the absence of $B d_{i}$ the reciprocal of the odds ratio (Table 2) was 5.9, suggesting an association of absence with relatively remote locations.

Although aquatic $\mathrm{pH}$ was slightly higher at infected sites (mean \pm SE: $6.0 \pm 0.24, \mathrm{n}=16$ ) than uninfected sites $(5.6 \pm 0.24, \mathrm{n}=46)$, the difference was not statistically significant $(t=1.72, \mathrm{df}=60, \mathrm{p}=0.08)$. The high $\mathrm{pH}$ at infected sites reflected an easterly bias in the sampling of infected sites where $\mathrm{pH}$ is generally higher. $B d$ was detected in tadpoles from acidic pools, with the lowest $\mathrm{pH}$ recorded being 5.1.

Chytridiomycosis was detected in the tadpole stage of all 4 frog species sampled (Litoria burrowsae, L. ewingii, Crinia tasmaniensis and C. signifera). However, it was not detected in any of the adult frogs sampled, although sample sizes were small ( $L$. burrowsae, $\mathrm{n}=6 ;$ L. ewingii, $\mathrm{n}=1$; Crinia spp., $\mathrm{n}=12$ ). There was little evidence to suggest that any of the frog species sampled were more or less likely to occur in areas where $B d$ was present (Table 3).

\section{DISCUSSION}

Understanding the distributional patterns of $B d$ and the identification of $B d$-free areas is essential for effective management and control of the pathogen (Skerratt et al. 2007, 2008). The results of our study suggest that most of the TWWHA remains free of $B d$ and that there is an opportunity to control the further spread of the disease into this valuable conservation area. There is some doubt about the ability of our strategy of largely targeting tadpoles with abnormal mouthparts to confidently determine if disease is absent from a site, and more sampling is needed to give confidence to this strategy in determining disease absence. The minimum estimated prevalence detected in our study of $16 \%$ based on very small sample sizes was below the minimum prevalence of $25 \%$ at which we can confidently say that $B d$ was absent based on a sample size of 12 (Skerratt et al. 2008). Therefore, there is a reasonable possibility that $B d$ was not detected at some sites. However, our study and that of Obendorf \& Dalton (2006) suggest that our strategy is good at detecting disease and is a suitable initial strategy to determine the distribution of $B d$ in Tasmania (Obendorf 2005, Obendorf \& Dalton 2006). Follow-up surveys can be used to give more confidence to disease absence in areas such as the TWWHA.

Understanding the processes involved in the dissemination of $B d$ will be critical to controlling the spread of the disease into the TWWHA as well as other disease-free areas of Tasmania. Three pieces of evidence indicate that anthropogenic processes rather than interspecific anuran transmission may be primarily responsible for facilitating the spread of the pathogen on a landscape scale in Tasmania: (1) the high incidence of $B d$ in landscapes associated with human disturbance and activity, particularly gravel roads, outside the borders of the TWWHA; (2) the 
Table 2. Batrachochytrium dendrobatidis $(B d)$. Contingency tables $(2 \times 2)$ showing the number of sites with $B d$ present or absent in relation to risk factors of human disturbance and the environment. Probability values from binary logistic models for associations between each individual factor and presence of $B d$ are shown

\begin{tabular}{|c|c|c|c|c|c|}
\hline $\begin{array}{l}\text { Factor present } \\
\text { or absent }\end{array}$ & $\begin{array}{l}\text { Number o } \\
\text { Bd present }\end{array}$ & $\begin{array}{l}\text { f sites with: } \\
B d \text { absent }\end{array}$ & $\begin{array}{c}\text { Infected } \\
(\%)\end{array}$ & $\begin{array}{l}\text { Odds ratio } \\
(95 \% \mathrm{CI})\end{array}$ & Probability \\
\hline \multicolumn{6}{|l|}{ Gravel road } \\
\hline Yes & 16 & 9 & 64 & (12-infinity) & $<0.001$ \\
\hline No & 0 & 37 & 0 & & \\
\hline \multicolumn{6}{|l|}{ Bitumen road } \\
\hline Yes & 1 & 10 & 9 & $0.24(0.01-2.0)$ & 0.12 \\
\hline No & 15 & 36 & 29 & & \\
\hline \multicolumn{6}{|l|}{ Walking track } \\
\hline Yes & 2 & 21 & 9 & $0.17(0.02-0.9)$ & 0.012 \\
\hline No & 14 & 25 & 36 & & \\
\hline \multicolumn{6}{|l|}{ Elevation } \\
\hline$<1000 \mathrm{~m}$ & 16 & 38 & 30 & (0.63-infinity) & 0.013 \\
\hline$\geq 1000 \mathrm{~m}$ & 0 & 8 & 0 & & \\
\hline \multicolumn{6}{|l|}{ Vegetation } \\
\hline Forest & 11 & 14 & 44 & $0.20(0.05-0.78)$ & 0.007 \\
\hline Non-forest & 5 & 32 & 14 & & \\
\hline
\end{tabular}

nearby wetlands is used to reduce dust formation during maintenance procedures, while moist soils may be transported long distances to repair the road structure. Water and soil run-off from the road surfaces into nearby wetlands during such procedures may facilitate the spread of waterborne $B d$ zoospores and infected tadpoles into new areas. $B d$ can persist for extended periods in water, moist soils and feathers without a host substrate (Johnson \& Speare 2003, 2005). Water collected from wild sources for use in dust suppression on gravel roads was suggested by Urban (2006) to facilitate the rapid dispersal of parasitic trematodes in northern Alaska. Similarly, soil and mud attached to heavy machinery and vehicles have been demonstrated to spread the plant pathogen Phytophthora into undisturbed forest communities in Australia

Table 3. Percentage of infected sites $(n=16)$ and uninfected sites $(\mathrm{n}=46)$ with frog species present. $B d$ : Batrachochytrium dendrobatidis

\begin{tabular}{|lcc|}
\hline Species & Bd present (\%) & Bd absent (\%) \\
\hline Crinia signifera & 63 & 43 \\
Crinia tasmaniensis & 56 & 72 \\
Litoria burrowsae & 19 & 26 \\
Litoria ewingii & 88 & 83 \\
\hline
\end{tabular}

absence of $B d$ throughout the more remote, relatively undisturbed regions of the TWWHA as indicated by the association of absence of $B d$ with walking tracks; and (3) Tasmanian frog species typically do not breed in stream habitats, thereby limiting the distribution of the pathogen by natural movement of water and anurans. However, if human-facilitated spread occurs in Tasmania, the mechanisms cannot be defined from the present study.

The presence of $B d$ was strongly associated with gravel roads. Roads can influence disease distribution by facilitating the translocation of pathogens (Daszak et al. 2000, Patz et al. 2004, Urban 2006), and road construction provides access to previously undisturbed locations. No association was found between the presence of $B d$ and roads sealed with bitumen, suggesting that the presence of the disease relates to some factor that specifically relates to gravel road construction, maintenance and/or where they occur. In Tasmania, regular road maintenance procedures for high-use gravel roads involve the transportation and relocation of soils and water along the road. Water collected from and America (Wills 1993, Jules et al. 2002). It is possible that the spread of $B d$ is also occurring through similar mechanisms in Tasmania, with the translocation of $B d$ and infected tadpoles in moist soils and mud on heavy machinery used in road maintenance operations.

\section{Risk to Tasmanian anurans}

$B d$ was detected in Litoria ewingii, L. burrowsae, Crinia tasmaniensis and C. signifera in pool habitats along the eastern and northern borders of the TWWHA. The potential impact of $B d$ on Tasmania's anurans is of significant concern, with 2 of Tasmania's 3 endemic anuran species restricted in range and habitat. Although significant population declines in these species have not been recorded, similarities in their life history traits and habitat preferences with declining anuran species throughout the world indicate that $\mathrm{Bd}$ poses a significant threat to these species.

The persistence and impact of $B d$ within a population or species depends on multiple factors (Berger et al. 1999, Daszak et al. 2003, Lips et al. 2003b). Obendorf (2005) hypothesised that widespread and abundant species including Litoria ewingii and Crinia signifera may, in some cases, act as reservoirs for $B d$ in Tasmania. The findings of Ricardo (2006) support this hypothesis, with captive $L$. ewingii metamorphs able to survive with high levels of $B d$ for at least $31 \mathrm{~d}$ post metamorphosis. However, further work on the susceptibility and survivorship of wild infected anurans in Tasmania is required. 


\section{Management}

The results of the present study indicate that the TWWHA is predominantly free of $B d$ and that humanfacilitated movement of the disease may be the main cause of spread across the landscapes investigated in our study rather than interspecific anuran transmission. Given that the majority of the TWWHA is not readily accessible by people, particularly by road, it may be feasible to control the spread of the disease in the TWWHA. Although further investigations into the precise mechanisms underlying human-facilitated movement are required to help management and control actions, a precautionary management approach should be adopted in relation to movement of water, soil and amphibians by people. This will involve identifying activities in which people currently transport water and soil into the TWWHA, assessing the risk of introducing the disease from these activities and adopting alternative measures where the risk is unacceptable. The transportation of amphibians into reserved land is currently illegal under the National Parks and Reserves Management Act 2002. We found an association between walking tracks and the absence of $B d$, suggesting an association between absence of the disease and remote areas, and that walking may be a low-risk activity for the spread of $B d$. Nevertheless, we recommend that walkers, as well as track construction workers, clean and disinfect their gear and equipment before commencing their activities. The public, land management agencies and researchers need to be informed about the disease, the consequences of spreading the disease and how they can avoid spreading the disease, particularly when visiting remote areas of the TWWHA. Monitoring sites need to be established at key locations within the TWWHA to detect further spread of the disease. Wherever possible, management of the disease should be linked with management of other important fungal diseases such as Mucor amphibiorum, which affects platypus, and Phytophthora cinnamomi, which affects plants.

Acknowledgements. The study was funded by Commonwealth and Tasmanian governments through the Tasmanian Wilderness World Heritage Area Fauna Program, Department of Primary Industries Parks, Water and Environment and Department of Environment and Heritage Funding Tender RFT 42/2004 on the epidemiology of chytridiomycosis to James Cook University. We thank H. Ricardo, B. Priest, S. Locke, D. Obendorf and J. Nelson for their advice and assistance in the field, R. Campbell and S. Cameron for conducting chytrid PCR tests, R. Brereton and Hydro Tasmania for helicopter support and access to remote areas of south-west Tasmania, Forestry Tasmania for access to State Forest lands, and the Tasmanian Parks and Wildlife Service for accommodation throughout the state. We also thank G. MacPherson for statis- tical advice on logistic regression. All work was undertaken under animal ethics approval (AEC 32/2006/07) and collection permits issued under the Nature Conservation Act 2002, National Parks and Reserved Land Management Act 2002 and Crown Lands Act 1976.

\section{LITERATURE CITED}

Australian Government Bureau of Meteorology (2006) Climate statistics for Australian sites. Available at www.bom. gov.au/climate/averages/tables/ca_tas_names.shtml

Australian Government Department of the Environment and Heritage (2006a) Threat abatement plan for infection of amphibians with chytrid fungus resulting in chytridiomycosis. Department of Environment and Heritage, Canberra. Available at www.environment.gov.au/biodiversity/threatened/publications/tap/chytrid/pubs/chytrid-re port.pdf

Australian Government Department of the Environment and Heritage (2006b) Background document for the threat abatement plan: infection of amphibians with chytrid fungus resulting in chytridiomycosis. Department of Environment and Heritage, Canberra. Available at www.deh.gov. au/biodiversity/threatened/publications/tap/chytrid/pubs /chytrid-background.pdf.

Bell BD, Carver S, Mitchell NJ, Pledger S (2004) The recent decline of a New Zealand endemic: How and why did populations of Archey's frog Leiopelma archeyi crash over 1996-2001? Biol Conserv 120:189-199

Berger L, Speare R, Daszak P, Green DE and others (1998) Chytridiomycosis causes amphibian mortality associated with population declines in the rain forests of Australia and Central America. Proc Natl Acad Sci USA 95: 9031-9036

Berger L, Speare R, Hyatt A (1999) Chytrid fungi and amphibian declines: overview, implications and future directions. In: Campbell A (ed) Declines and disappearances of Australian frogs. Environment Australia, Canberra, p 22-23

Berger L, Speare R, Hines H, Marantelli G and others (2004) Effect of season and temperature on mortality in amphibians due to chytridiomycosis. Aust Vet J 82:434-439

Bosch J, Martínez-Solano I, García-París M (2001) Evidence of a chytrid fungus infection involved in the decline of the common midwife toad (Alytes obstetricans) in protected areas of central Spain. Biol Conserv 97:331-337

Boyle DG, Boyle DB, Olsen V, Morgan JAT, Hyatt AD (2004) Rapid quantitative detection of chytridiomycosis (Batrachochytrium dendrobatidis) in amphibian samples using real-time Taqman PCR assay. Dis Aquat Org 60:141-148

Daszak P, Cunningham AA, Hyatt AD (2000) Emerging infectious diseases of wildlife - threats to biodiversity and human health. Science 287:443-449

$>$ Daszak P, Cunningham AA, Hyatt AD (2003) Infectious disease and amphibian population declines. Divers Distrib 9: $141-150$

> Diaz L, Cadiz A, Chong A, Silva A (2007) First report of chytridiomycosis in a dying toad (Anura: Bufonidae) from Cuba: a new conservation challenge for the island. EcoHealth 4:172-175

Driessen MM, Mallick SA (2003) The vertebrate fauna of the Tasmanian Wilderness World Heritage Area. Pac Conserv Biol 9:187-206

> Garner TWJ, Walker S, Bosch J, Hyatt AD, Cunningham AA, Fisher MC (2005) Chytrid fungus in Europe. Emerg Infect Dis 11:1639-1641

Green DE, Kagarise Sherman C (2001) Diagnostic histological 
findings in Yosemite Toads (Bufo canorus) from a die-off in the 1970s. J Herpetol 35:92-103

Green DE, Converse KA, Schrader AK (2002) Epizootiology of sixty-four amphibian morbidity and mortality events in the USA, 1996-2001. Ann NY Acad Sci 969:323-339

Hyatt AD, Boyle DG, Olsen V, Boyle DB and others (2007) Diagnostic assays and sampling protocols for the detection of Batrachochytrium dendrobatidis. Dis Aquat Org 73: 175-192

Johnson ML, Speare R (2003) Survival of Batrachochytrium dendrobatidis in water: quarantine and control implications. Emerg Infect Dis 9:922-925

Johnson ML, Speare R (2005) Possible modes of dissemination of the amphibian chytrid Batrachochytrium dendrobatidis in the environment. Dis Aquat Org 65:181-186

> Jules ES, Kauffman MJ, Ritts WD, Carroll AL (2002) Spread of an invasive pathogen over a variable landscape: a nonnative root rot on Port Orford cedar. Ecology 83:3167-3181

La Marca E, Lips KR, Lotters S, Puschendorf R and others (2005) Catastrophic population declines and extinctions in Neotropical harlequin frogs (Bufonidae: Atelopus). Biotropica 37:190-201

> Lane EP, Weldon C, Bingham J (2003) Histological evidence of chytridiomycosis in a free-ranging amphibian (Afrana fuscigula (Anura: Ranidae)) in South Africa. J S Afr Vet Assoc 74:20-21

Lips KR, Green DE, Papendick R (2003a) Chytridiomycosis in wild frogs from Southern Costa Rica. J Herpetol 37: 215-218

Lips KR, Reeve JD, Witters LR (2003b) Ecological traits predicting amphibian population declines in Central America. Conserv Biol 17:1078-1088

Lips KR, Brem F, Brenes R, Reeve JD and others (2006) Emerging infectious disease and the loss of biodiversity in a Neotropical amphibian community. Proc Natl Acad Sci USA 103:3165-3170

Lips KR, Diffendorfer J, Mendelson III Jr, Sears MW (2008) Riding the wave: reconciling the roles of disease and climate change in amphibian declines. PLoS Biol 6:e72. doi:10.1371/journal.pbio.0060072

> Mazzoni R, Cunningham AC, Daszak P, Apolo A, Perdomo E, Speranza G (2003) Emerging pathogen of wild amphibians in frogs (Rana catesbiana) farmed for international trade. Emerg Infect Dis 9:995-998

Muths E, Corn PS, Pessier AP, Green DE (2003) Evidence for disease related amphibian decline in Colorado. Biol Conserv 110:357-365

Obendorf D (2005) Developing field and diagnostic methods to survey for chytridiomycosis in Tasmanian frogs. Department of Environment and Heritage, Canberra. Available at: www.environment.gov.au/biodiversity/invasive/publications/tasmanian-frogs.html

Obendorf D, Dalton A (2006) A survey for the presence of the amphibian chytrid fungus (Batrachochytrium dendrobatidis) in Tasmania. Pap Proc R Soc Tasman 140:25-29

Parker JM, Mikaelian I, Hahn N, Diggs HE (2002) Clinical

Editorial responsibility: Alex Hyatt,

Geelong, Victoria, Australia diagnosis and treatment of epidermal chytridiomycosis in African clawed frogs (Xenopus tropicalis). Comp Med 52:265-268

Patz JA, Daszak P, Tabor GM, Aguirre AA and others (2004) Unhealthy landscapes: policy recommendations on land use change and infectious disease emergence. Environ Health Perspect 112:1092-1098

Retallick RWR (2003) Bioclimatic investigations into the potential distribution of Batrachochytrium dendrobatidis in Australia. Department of Zoology and Entomology, University of Queensland, Brisbane, and School of Public Health, Tropical Medicine and Rehabilitation Sciences, James Cook University, Townsville

Ricardo H (2006) Distribution and ecology of chytrid in Tasmania. Honours thesis. University of Tasmania, Hobart

Ron SR, Merino A (2000) Amphibian declines in Ecuador: overview and first report of chytridiomycosis from South America. Froglog 42:2-3

Skerratt LF, Berger L, Speare R, Cashins S and others (2007) Spread of chytridiomycosis has caused the rapid global decline and extinction of frogs. EcoHealth 4:125-134

Skerratt LF, Berger L, Hines HB, McDonald KR, Mendez D, Speare R (2008) Survey protocol for detecting chytridiomycosis in all Australian frog populations. Dis Aquat Org 80:85-94

Speare R (2001) Developing management strategies to control amphibian diseases: decreasing the risks due to communicable diseases. School of Public Health and Tropical Medicine, James Cook University, Townsville. Available at www. jcu.edu.au/school/phtm/PHTM/frogs/adms/scope. htm

Speare R, Skerratt L, Berger L, Hines H and others (2005) A project that designs and trials a pilot survey to map the distribution of chytridiomycosis (caused by the amphibian chytrid) in Australian frogs. Final report for Project ID 44381 (tender 63/2003) to the Australian Government Department of Environment and Heritage. Available at: www.deh.gov.au/biodiversity/invasive/publications/cdisease/distribution-survey.html.

Urban MC (2006) Road facilitation of trematode infections in snails of Northern Alaska. Conserv Biol 20:1143-1149

Weldon C (2002) Chytridiomycosis survey in South Africa. Froglog 51:1-2

Weldon C, du Preez LH, Hyatt AD, Muller R, Speare R (2004) Origin of the amphibian chytrid fungus. Emerg Infect Dis 10:2100-2105

Williams ES, Yuill T, Artois M, Fischer J, Haigh SA (2002) Emerging infectious diseases in wildlife. Rev Sci Tech (OIE) 2:139-157

Wills RT (1993) The ecological impact of Phytophthora cinnamomi in the Stirling Ranges National Park, Western Australia. Aust J Ecol 18:145-159

Witte CL, Sredl MJ, Kane AS, Hungerford LL (2008) Epidemiological analysis of factors associated with local disappearances of native ranid frogs in Arizona. Conserv Biol 22:375-383

Submitted: June 2, 2009; Accepted: February 3, 2010

Proofs received from author(s): May 20, 2010 